\title{
Effect of environmental improvements on the diatoms of the River Axe, southern England
}

\author{
Martyn G. Kelly ${ }^{1 *}$, Andrew Haigh ${ }^{2}$, Jeanette Colette $^{2}$ \& Aleksandra ZGRUndo ${ }^{3}$ \\ ${ }^{1}$ Bowburn Consultancy, 11 Monteigne Drive, Bowburn, Durham DH6 5QB, UK; *corresponding author e-mail: \\ MGKelly@bowburn-consultancy.co.uk \\ ${ }^{2}$ Environment Agency, Miller's Way, Exminster, Devon EX6 8AS, UK \\ 3 University of Gdansk, Institute of Oceanography, Al. Pilsudskiego 46, Gdynia 81-378, Poland
}

\begin{abstract}
The River Axe, a lowland river in South-west England is used as a model system for describing how ecological status assessments can be applied in practice. Seasonal sampling over a three-year period established a strong baseline against which future changes could be assessed. These indicated that the river was enriched with nutrients and that ecological status was significantly below the good/moderate status boundary, implying the need for a Programme of Measures to be implemented. Reductions in both point and diffuse sources of nutrients led to changes in the diatom assemblage, reflected by increasing EQRs at monitored sites. An understanding of the uncertainty inherent in diatom-based ecological status assessments allows the success of control measures to be assessed. In the case of the River Axe, diatom-based assessments suggest that the river is now close to good status at many monitored sites, although there is still evidence of some nutrient enrichment.
\end{abstract}

Key words: diatoms, monitoring, nutrients, Water Framework Directive

\section{Introduction}

ZelinKa \& MaRvan (1961) introduced the weighted average equation to freshwater ecology, thus providing an objective and quantitative means of summarising changes in often-complex assemblages of species along environmental gradients. The approach has been used widely by diatomists, both for the measurement and assessment of pollution in rivers (DESCY 1979; Coste in CEMAGREF 1982, Kelly \& Whitton 1995) and for environmental reconstructions (BIRKs et al. 1990, BenNion et al. 1996). The equation is the basis for many methods developed to meet the requirements of the Water Framework Directive (WFD; EUROPEAN UNION 2000; see KELLY et al. 2009a) and, therefore, plays a significant role in water management in Europe, almost half a century after it was first introduced.

The WFD has spawned a huge quantity of research in recent years (Tison et al. 2005, RIMET et al. 2004, Schaumburg et al. 2004, Kelly et al. 2008); most of which shares two features. The first is that almost all national methods are based on indices developed prior to the WFD, and which focus on establishing a strong relationship between diatoms and water quality, rather than attempting to assess ecological status directly. The second is that, until now, the focus has been - rightly - on establishing approaches for surveillence that can be applied consistently within an entire country and which are, thanks to intercalibration exercises, comparable within broader regions (BIRKs \& Hering 2009, Kelly et al. 2009a). However, having identified those water bodies that fail to achieve "good ecological status (GES)", Member States are then required to apply "Programmes of Measures" in order for these to achieve GES. In order to do this, they will need to identify those pollution sources that are responsible for the failures within a water body in order to ensure that investment in water quality improvements leads to benefits in ecological status. This paper describes an instance where diatoms were analysed with a view to providing decision-makers with the information they need to plan the measures necessary to bring about ecological improvements. As the WFD is not yet fully in force in the UK this is not technically a Programme of Measures designed to bring this water body back to GES, but an example drawn from UK implementation of the Habitats Directive 
(European Community 1992) from which lessons relevant to the WFD may be learnt. The paper then goes on to describe the consequences for the diatom flora of such steps and to highlight some issues about how ecological status concepts should be understood and applied. This final point is important because, whilst weighted averaging has proved to be a valuable means for summarising chemical information, there is a danger that the indiscriminate use of metrics based on this equation will result in the loss of valuable ecological information. This happens, in part, because diatom-based metrics, by their very nature, ignore changes in non-diatom components of stream floras (KeLLY et al. 2009c) but also because these metrics were developed in an era before ecological health concepts were integral to river basin management.

\section{Materials and methods}

\section{Study site}

The River Axe rises at $190 \mathrm{~m}$ above sea level in rich agricultural land over the mixed geology (mostly Triassic mudstones and Cretaceous sandstones) of south Devon, and flows $45 \mathrm{~km}$ west, then southwest to join the English Channel at Seaton (Fig. 1). Nutrient concentrations are high due to a combination of intensive agriculture along with a creamery, whose effluents enter the river at $\mathrm{km} 22$ (Chard) and various small sewage works, the largest of which is downstream of Axminster ( $\mathrm{km} \mathrm{32).} \mathrm{Despite} \mathrm{this,}$ the section between Wadbrook (approx. km 25) and Colyford, at the tidal limit ( $\mathrm{km} \mathrm{45)} \mathrm{has} \mathrm{been} \mathrm{designated}$

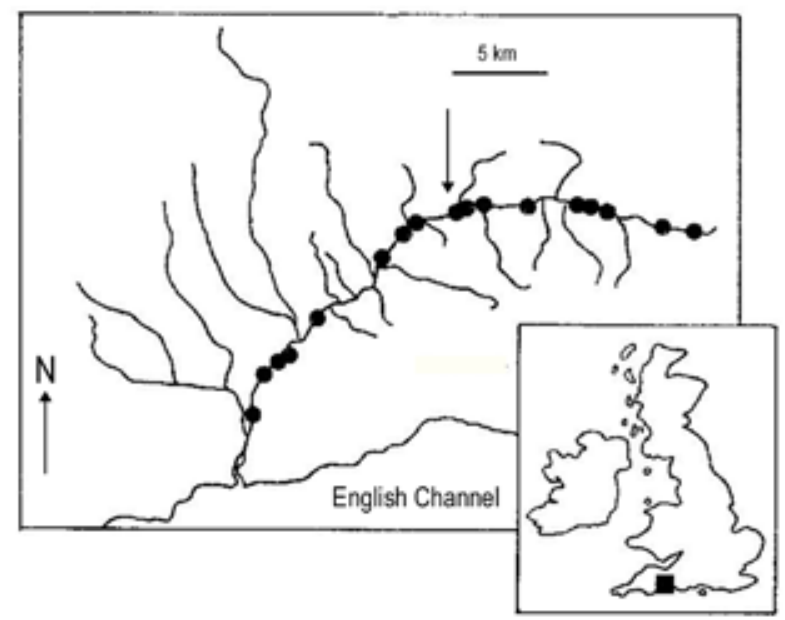

Fig. 1. The River Axe, showing location of sample sites on the main river. Arrow indicates the position of the input from St Ivel creamery. Inset: location of River Axe catchment within Great Britain as a Special Area of Conservation, under the terms of the Habitats Directive (EUROPEAn COMMUNITy 1992), as a representative example of a "water course of plain to montane levels with the Ranunculion fluitantis and Callitricho-Batrachion vegetation". The mixed catchment geology of sandstones and limestones gives rise to calcareous waters where Ranunculus penicillatus ssp. pseudofluitans (SYME) S. WeBSTER dominates, giving way to $R$. fluitans LAM. further downstream. Short-leaved water-starwort Callitriche truncata Guss. is an unusual addition to the Ranunculus community for the UK and gives additional interest. Cladophora glomerata (L.) KüTZ. is common throughout the catchment. Although the invertebrate fauna is healthy (Environment AgEnCy, unpublished data), there have been problems with salmonid recruitment in recent years, thought to be due to siltation of breeding grounds. There are, in addition, three fish species of European importance (bullhead Cottus gobio L., brook lamprey Lampetra planeri BLOCH, and sea lamprey Petromyzon marinus L.).

Mass balance modelling in 2004 (AsH et al. 2004) showed that about 63 tonnes per annum of phosphorus entered the river, split almost equally between point and diffuse sources. About half the point source load came from a single input - a discharge from the creamery at $\mathrm{km} 22$.

\section{Diatom sampling and analysis}

15 sample sites were selected along the River Axe, in order to permit the influence of key inputs and tributaries to be differentiated. A sample was collected from each site in spring (March - May); summer (June - August) and autumn (September - November) of 2002 and 2003. In addition, summer and autumn samples were collected in 2001 and some sampling also took place in 1998. A limited sampling program continued after diffuse nutrient control measures had been introduced in parts of the catchment between 2004 and 2006, with samples collected from five sites on the River Axe, located close to areas where these control measures had been implemented, along with tributary streams draining catchments where control measures had also been implemented.

Five cobbles were collected from mid-stream and placed into a tray with a little stream water and the top surface of each was brushed with a clean toothbrush in order to remove the biofilm (KeLly et al. 1998; CEN 2003). The resulting suspension was collected in a plastic bottle, fixed with Lugol's iodine and stored prior to analysis. Samples were digested either in a saturated solution of potassium permanganate and concentrated hydrochloric acid (HENDEY 1974) or with hydrogen peroxide (BATTARBEE 1986). Permanent slides were prepared using Naphrax (refractive index $=1.74$, Brunel Microscopes Ltd) as a mountant.

At least 300 valves on each slide were identified to the highest resolution possible and usually species 
or variety (CEN 2004). The primary floras and identification guides used were KRAMMER and LANGEBertalot (1986, 1997, 2000, 2004) and Hartley, BARBER and CARTER (1996). All nomenclature was adjusted to that used by WhitTon et al. (1998) which follows conventions in Round, CRAWFORD \& MANN (1990) and Fourtanier \& KocIOLEK (1999).

\section{Data analysis}

The Trophic Diatom Index (TDI) was calculated for all samples, and used to derive Ecological Quality Ratios (EQRs) as (100 - observed TDI] / [100 - expected TDI]. The expected TDI for rivers was calculated using the algorithm in KeLLy et al. (2008) which uses alkalinity and season as variables. Annual mean total alkalinity data are available only for 2003 and not for all sites. Values for sites that lacked measurements are the means of the upstream and downstream values. As total alkalinity levels are high in the Axe, the effect of these interpolations is insignificant.

The Trophienindex of RotT et al. (1999) and the Trophic index of CoRING et al. (1999) were also calculated but these gave very similar results to the TDI and are not shown in this paper.

Chemical data were supplied by the Environment Agency and consist of averages of monthly samples.

\section{Results}

Annual mean nutrient concentrations in the River Axe between 2000 and 2003 were elevated with even sites close to the source close to the target concentration for phosphorus for "good ecological status" in lowland high alkalinity rivers (Fig 2). There is a sharp increase in $P$ concentration downstream of the creamery at Chard $(\mathrm{km} \mathrm{22})$ and it remains elevated until the tidal limit whilst $\mathrm{N}$ concentrations show a gradual increase until approximately $\mathrm{km} 25$ and then decline again towards the tidal limit. Analyses of elemental ratios (not presented here) suggest that $\mathrm{P}$ was more likely to be the limiting nutrient throughout the catchment, though other factors (e.g. light, temperature) may also have limited primary production.

Achnanthidium minutissimum (KÜTZ.) CZARNECKI was abundant in samples from the first $10 \mathrm{~km}$ of the River Axe, particularly in spring. At other times of the year and at all sites downstream from here, however, samples were dominated by taxa more indicative of moderate or high nutrient concentrations. The spring samples at these lower sites were dominated by Navicula lanceolata (AG.) EHRENB.and Navicula gregaria DonKIN, whilst autumn samples were dominated by Amphora pediculus (KüTz.) Grunow. These seasonal changes are fairly characteristic of lowland rivers in the UK.

TDI values in the River Axe showed relatively little longitudinal variation, except at the uppermost sites (Fig. 3a). The mean EQR value for all sites fell below the threshold EQR value of 0.68 , and only two samples from Cheddington, the uppermost site, falling into high or good status (Fig. 3b). The first three sites on the river (Cheddington, $\mathrm{u} / \mathrm{s}$ and $\mathrm{d} / \mathrm{s}$ Mosterton) all had three-year mean values that indicated moderate status but all other sites would be classified at poor status on the basis of these results.

Phosphorus concentrations declined throughout the study period (Fig. 4). Data for Whitford Bridge, a site downstream of major point and diffuse inputs, show this clearly, with a steep decline from a peak in the middle of 2001, as production was scaled back at the creamery, followed by a more gradual decline from early 2004 onwards, as diffuse pollution controls were introduced. However, P concentrations in the river still oscillate around the target concentration of $0.125 \mathrm{mg} \mathrm{l}^{-1}$. These nutrient reductions led to a concomitant increase in EQR at the five sites on the main river where monitoring continued (Fig. 3b), caused principally by an increase in the proportion of Achnanthidium spp in the samples. This was particularly pronounced at Broom (Fig. 5a), demonstrating a rising trend, starting in the middle of 2003, and continuing until the end of the study, when samples were achieving good ecological status. A similar trend was observed when all data from sites (main river and tributaries) monitored from 2004 onwards were pooled (Fig. $5 b)$ with a significant $(\mathrm{P}<0.001)$ upward trend in EQRs. At least two forms of Achnanthidium were observed in these samples: Achnanthidium minutissimum (KÜTZ.) CZARNECKI sensu stricto along with small, rhombic-lanceolate valves attributed to Achnanthidium cf. eutrophilum (Lange-Bert.) Lange-Bert.

\section{Discussion}

A key objective of the WFD is that all water bodies should achieve good ecological status by 2015 (European Union 2000: Article 4). Until now, discussion in the literature has focussed primarily on developing means of establishing 

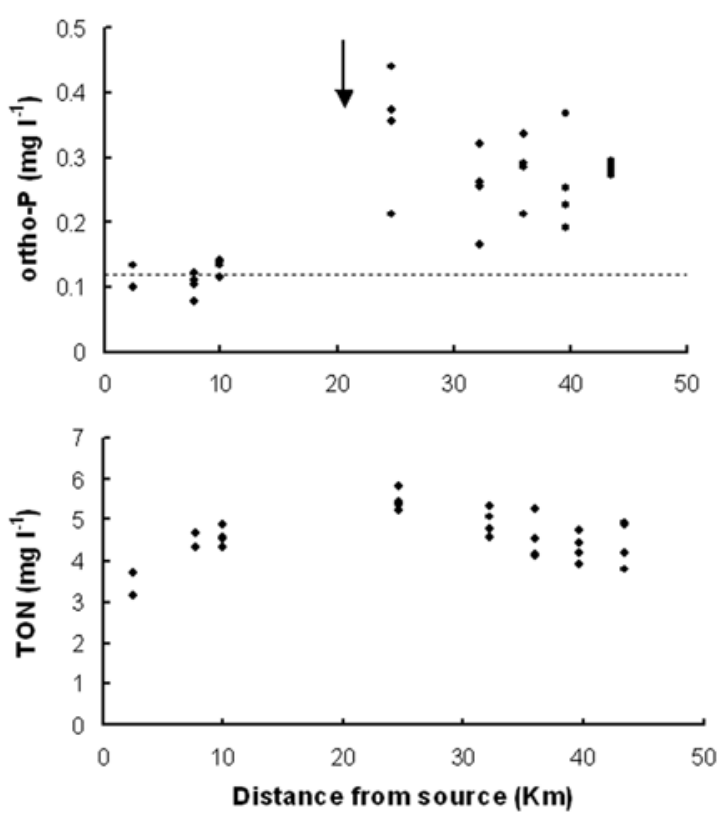

Fig. 2. Longitudinal change in annual mean concentrations of a) dissolved phosphorus (orthophosphate-P) and b) total oxidised nitrogen (TON) in the River Axe between 2000 and 2003. The source is defined as the furthest upstream point of the river which appears on an Ordnance Survey 1:50000 scale map. Dotted line indicates position of the proposed regulatory standard for $\mathrm{P}$ in lowland, high alkalinity UK rivers $\left(0.125 \mathrm{mg} \mathrm{l}^{-1}\right.$; no similar standard exists for $\left.\mathrm{N}\right)$. Arrow indicates the location of the creamery.

transferable concepts about how ecological status should be assessed (Hering et al. 2006, Kelly et al. 2009a) and less on how ecological data can be used to support decision making at the catchment scale. In this study, several components of a classic before-after-control-impact study (BACI; UNDERWOOD 1991) are in place, with an extensive period of monitoring prior to the introduction of control measures in order to establish a baseline against which future changes can be assessed.

The Axe presents an interesting paradox being simultaneously, a river of apparently high conservation value yet clearly nutrient enriched and unlikely to achieve good ecological status. Changing land use practices within the catchment may explain part of this, with the possibility that the rapidly-responding diatom assemblages were indicating a situation that could, in time, lead to degradation of the slower-responding macrophytes unless action was taken.

Decisions to implement Programmes of Measures cannot be taken lightly, as large investment is required, impacting both on public finances and the profitability of private
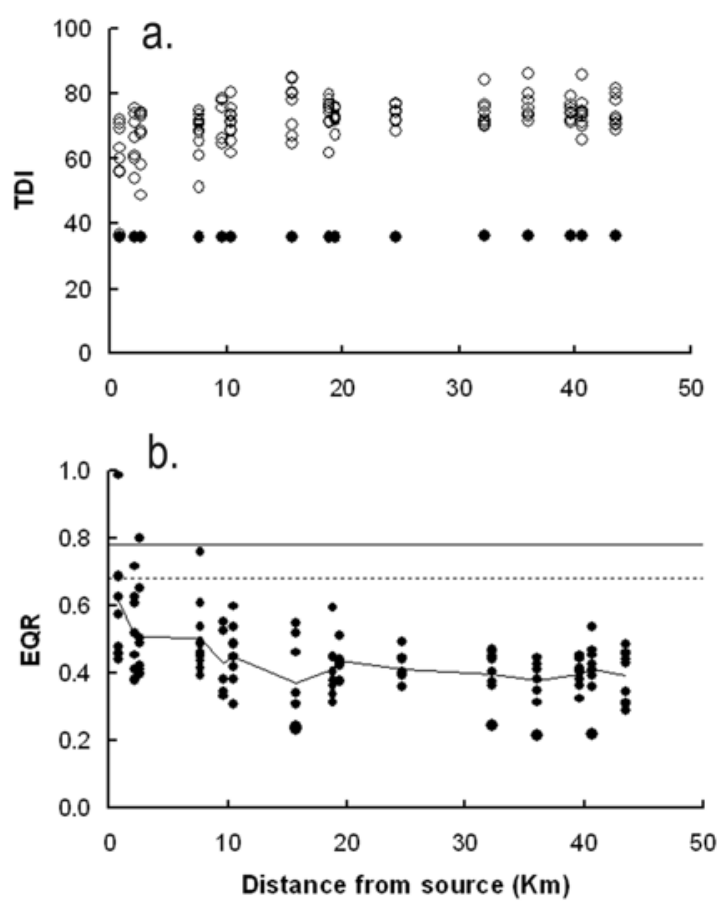

Fig. 3. (a) observed (closed circles) and expected (open circles) values of the TDI in the River Axe; (b) EQR values in the River Axe, based on data collected between 1998 and 2003 (closed circles) and between 2004 and 2006 (open circles). Solid line indicates the mean EQR value at each site. The solid line represents the boundary between good and moderate ecological status whilst the dashed line corresponds to $\mathrm{EQR}=0.68$ (the point on the $\mathrm{EQR}$ scale when there is $>95 \%$ confidence that a site is not at good status - see KeLLY et al., 2009b for more details).

enterprises. Whilst water quality planners have experience of linking pollutant loads in rivers to known sources via mass-balance models (e.g. HowDEN et al. 2009), the WFD introduces an extra tier of uncertainty, as the primary criterion for establishing whether a river achieves desired status is ecological. The fast growth rates and rapid community turnovers means that diatoms respond rapidly to environmental changes (see above) although, at the same time, this can mean that diatom assemblages are more variable than assemblages of other organism groups (SPRINGE et al. 2006, Lavoie et al. 2008). Kelly et al. (2009b) describe the implications of different sample sizes on uncertainty, pointing out that a sample that is close to a boundary inevitably has a relatively high risk of misclassification. Modelling, based on these data, has allowed the point on the EQR gradient where one can be $95 \%$ certain that a site is not at high or good status to be identified and we can therefore state, with a high degree of 


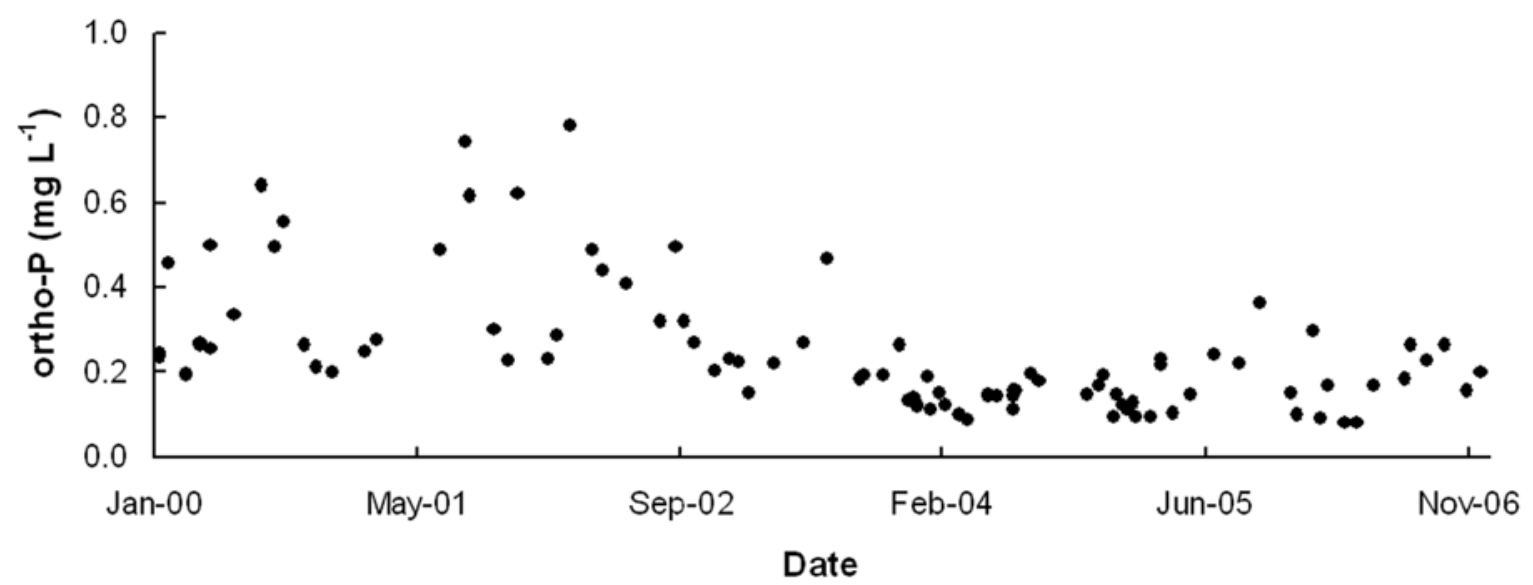

Fig. 4. P (as ortho-phosphate) concentrations in the River Axe at Broom (km 25), between 2000 and 2006.

confidence that a Programme of Measures on a river such as the Axe is likely to yield ecological benefits.

This was, indeed, the case, with a pronounced change in the TDI and EQR accompanying the nutrient control measures, reflecting a shift in community composition away from one dominated largely by motile taxa and towards one where short-stalked Achnanthidium was more abundant. Interpretation is not, however, straightforward as the Achnanthidium-dominated assemblage was actually a mixture of $A$. minutissimum and $A$. cf. eutrophilum, the latter having a preference for more nutrient-rich waters (PoTAPOVA \& HAMILTON 2007). Some diatom metrics (e.g. Indice de Polluosensiblité, Coste in CEMAGREF 1982) would have applied separate sensitivity value to these two taxa and, perhaps, damped down the effect of changes in the River Axe. This raises an interesting question about whether a change in species composition necessarily indicates a change in ecological status or whether it is possible for a change in pressure to result in a change in composition but for the ecological status to remain unchanged. The WFD defines ecological status as "an expression of the structure and functioning of aquatic ecosystems" (European Union 2000: Article 2) and we argue that a change from a largely-motile assemblage to one with a high proportion of stalked diatoms suggests a significant change in structure and, therefore, qualifies as a change in status. The presence of $A$. eutrophilum should not, therefore, influence the status designation per se although it serves as a warning that nutrient levels are still elevated. This problem is compounded by the relatively
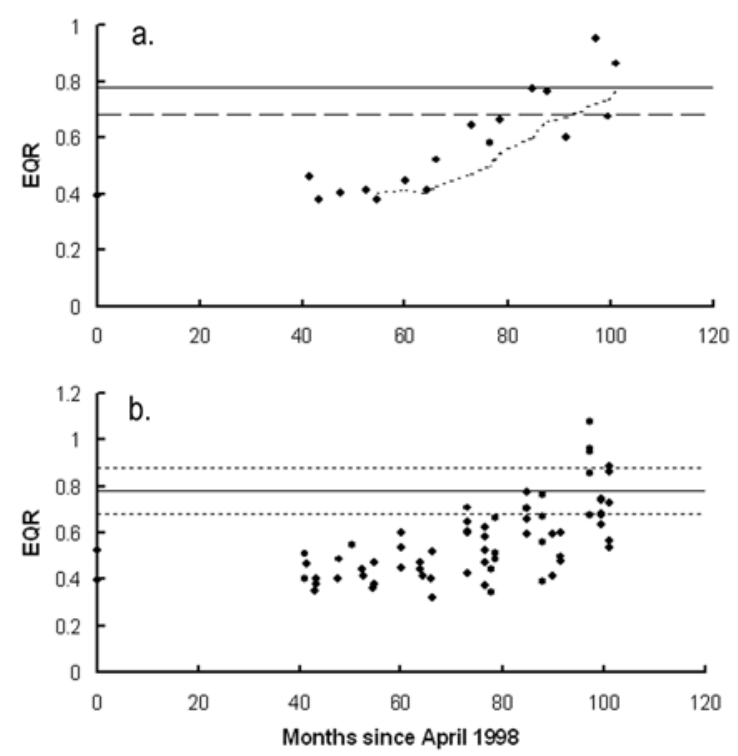

Fig. 5. (a) change in EQR over time at Broom. Trend line is moving average based on $n=6$ samples; (b) change in EQR at all sites (main river and tributary) monitored from 2004 onwards. $\mathrm{R}^{2}=0.36$. Dashed lines indicate $\mathrm{EQR}=0.68$ (the point on the EQR scale when there is $>95 \%$ confidence that a site is not at good status) and $\mathrm{EQR}=0.88$ (the point on the EQR scale when there is $>95 \%$ confidence that a site is not at moderate status or less).

uncritical adoption of existing metrics to fulfil the needs of the WFD (exemplified by Hering et al. 2006) and by a focus on the various biological quality elements separately rather than development of an integrated view of "ecological status" that reflects how different organism groups knit together within the stream ecosystem. To this end, we suggest that grazing invertebrates are probably better judges of whether a shift in species composition of diatoms is significant 
than taxonomists, however experienced. This opens the door towards a second generation of tools for evaluating ecological status, integrating information from across taxonomic groups.

\section{Acknowledgements}

This paper is dedicated to Petr Marvan, whose contributions have had a profound influence on modern biological monitoring. This project was funded by the Environment Agency as part of the EU funded Cycleau Project 2003 - 2007. Views expressed in this paper do not necessarily represent the final or policy positions of the Environment Agency.

\section{References}

Ash, T., Murdoch, N. \& Pope, L. (2004): Analysis and modelling of phosphorus. -46pp. Environment Agency, South-west Region, Exeter.

Battarbee, R.W. (1986): Diatom analysis. - In: Berglund, B.E. (ed.): Handbook of Holocene Palaeoecology and Palaeohydrology. - pp. 527570, Wiley, Chichester.

Bennion, H., Juggins, S. \& Anderson, N.J. (1996): Predicting epilimnetic phosphorus concentrations using an improved diatom-based transfer function and its application to lake eutrophication management. - Environmental Science and Technology 30: 2004-2007.

Bennion, H., Fluin, J. \& Simpson, G.L. (2004): Assessing eutrophication and reference conditions for Scottish freshwater lochs using subfossil diatoms. - Journal of Applied Ecology 41: 124-138.

Birk, S. \& Hering, D. (2009): A new procedure for comparing class boundaries of biological assessment methods: a case study from the Danube Basin. - Ecological Indicators 9: 528539.

Birks, H.J.B., Line, J.M., Juggins, S., Stevenson, A.C. \& TER BRAAK, C.J.F. (1990): Diatoms and $\mathrm{pH}$ reconstruction. - Philosophical Transactions of the Royal Society of London, Series B 327: 263-278.

CEMAGREF (1982): Etude de Méthodes Biologiques Quantitatives d'Appreciation de la Qualité des Eaux. - Rapport Q.E. Lyon-A.F.B. RhôneMediterrannée-Corse.

CEN (2003): Water quality - Guidance standard for the routine sampling and pretreatment of benthic diatoms from rivers. - EN 13946: 2003; Comité European de Normalisation, Geneva.

CEN (2004): Water quality - Guidance standard for the identification, enumeration and interpretation of benthic diatom samples from running waters. - EN 14407:2004; Comité European de Normalisation, Geneva.

Coring, E., Schneider, S., Hamm, A. \& Hofmann, G. (1999): Durchgehendes Trophiesystem auf der Grundlage der Trophieindikaation mit Kieselalgen. - 219 pp., Deutscher Verband für Wasserwirtschaft und Kulturbau e.V., Koblenz.

DESCY, J-P. (1979): A new approach to water quality estimation using diatoms. - Nova Hedwigia 64: 305-323.

European Community (1992): Council Directive of 21 May 1992 Concerning the Conservation of Natural Habitats and of Wild Flora and Fauna. - Official Journal of the European Community, Series L, p. 206.

European Union (2000): Directive 2000/60/EC of the European Parliament and of the Council of 23 October 20000 establishing a framework for Community action in the field of water policy. Official Journal of the European Communities, Series L 327: 1-73.

Fourtanier, E. \& Kociolek, J.P. (1999): Catalogue of the diatom genera. - Diatom Research 14: $1-190$.

Hartley, B., Barber, H.G. \& Carter, J.R. (1996): An Atlas of British Diatoms. - In: Sims, P.A. (ed.). - 601 pp., Biopress, Bristol.

Hendey, N.I. (1974): The permanganate method for cleaning freshly gathered diatoms. - Microscopy 32: 423-426.

Hering, D., Johnson, R.K., Kramm, S., Schmutz, S., Szoszkiewicz, K. \& Verdonschot, P.F.M. (2006): Assessment of European streams with diatoms, macrophytes, macroinvertebrates and fish: a comparative metric-based analysis of organism resonse due to stress. - Freshwater Biology 51: 1757-1785.

Howden, N.J.K., Bowes, M.J., Clark, A.D.J., Humphries, N. \& Neal, C. (2009): Water quality, nutrients and the European union's Water Framework Directive in a lowland agricultural region: Suffolk, south-east England. - Science of the Total Environment 407: 2966-2979.

Kelly, M.G. \& Whitton, B.A. (1995): The Trophic Diatom Index: a new index for monitoring eutrophication in rivers. - Journal of Applied Phycology 7: 433-444.

Kelly, M.G., Cazaubon, A., Coring, E., Dell'Uomo, A., Ector, L, Goldsmith, B., Guasch, H., Hürlimann, J., Jarlman, A., Kawecka, B., Kwandrans, J., Laugaste, R., Lindstrøm, E.-A., Leitao, M., Marvan, P., Padisák, J., Pipp, E., Prygiel, J., Rott, E., Sabater, S., van Dam, H. \& VizineT, J. (1998): Recommendations for the routine sampling of diatoms for water quality assessments in Europe. - Journal of Applied Phycology 10: 215-224.

Kelly, M.G., Juggins, S., Guthrie, R., Pritchard, S., 
Jamieson, J., Rippey, B, Hirst, H. \& Yallop, M. (2008): Assessment of ecological status in U.K. rivers using diatoms. - Freshwater Biology 53: 403-422.

Kelly, M.G., Bennett, C., Coste, M, Delgado, C., Delmas, F. Denys, L., Ector, L., Fauville, C., Ferreol, M., Golub, M., Jarlman, A., Kahlert, M., Lucey, J., Ní Chatháin, B., Pardo, I, Pister, P., Picinska-Faltynowicz, J., Rosebery, J., Schranz, C., Schaumburg, J.,van Dam, H. \& Vilbaste, S. (2009a): A comparison of national approaches to setting ecological status boundaries in phytobenthos assessment for the European Water Framework Directive: results of an intercalibration exercise. - Hydrobiologia, doi 10.1007/s10750-008-9641-4.

Kelly, M.G., Bennion, H., Burgess, A., Ellis, J., Juggins, J., Guthrie, R., JAMIESON, B.J., Adriaenssens, V. \& Yallop, M.L. (2009b): Uncertainty in ecological status assessments of lakes and rivers using diatoms. - Hydrobiologia, (in press).

Kelly, M.G., King, L. \& ní ChathÁin, B. (2009c): The conceptual basis of ecological quality assessments using diatoms. - Proceedings of the Royal Irish Academy: Biology and Environment, (in press).

Krammer, K. \& Lange-Bertalot, H. (1986): Bacillariophyceae, 1 Teil: Naviculaceae. - In: Ettr, H., GÄrtner, G., Gerloff, J., Heynig, H. \& Mollenhauer, D. (eds): Die Süsswasserflora von Mitteleuropa 2. - 876 pp., Gustav FischerVerlag, Stuttgart.

Krammer, K. \& Lange-Bertalot, H. (1997): Bacillariophyceae. Teil 2: Bacillariaceae, Epithemiaceae, Surirellaceae. - In: ETTL, H., Gärtner, G., Gerloff, J., Heynig, H. \& Mollenhauer, D. (eds): Süßwasserflora von Mitteleuropa 2/2 . - 594 pp., Gustav Fischer Verlag, Stuttgart.

Krammer, K. \& LAnge-Bertalot, H. (2000): Bacillariophyceae, 3 Teil: Centrales, Fragilariaceae, Eunotiaceae. - In: Ettr, H., Gärtner, G., Gerloff, J., Heynig, H. \& Mollenhauer, D. (eds): Die Süsswasserflora von Mitteleuropa 2/ . - 599 pp., Gustav Fischer Verlag, Stuttgart.

Krammer, K. \& Lange-Bertalot, H. (2004): Bacillariophyceae, Teil 4: Achnanthaceae. Kritische Ergänzungen zu Achnanthes s.l., Navicula s. str., Gomphonema. - In: EtTL, H., Gärtner, G., Gerloff, J., Heynig, H. \& Mollenhauer, D. (eds): Süsswasserflora von Mitteleuropa 2/ . - 468 pp., Spektrum Akademischer Verlag/Gustav Fischer, Heidelberg.

Lavoie, I., Campeau, S., Darchambeau, F., Cabana, G. \& Dillon, D.J. (2008): Are diatoms good integrators of temporal variability in stream water quality? - Freshwater Biology 53: 827841.

Potapova, M. \& Hamilton, P.B. (2007): Morphological and ecological variation within the Achnanthidium minutissimum (Bacillariophyceae) species complex. - Journal of Phycology 43: 561-575.

Rott, E., Pipp, E., Pfister, P., van Dam, H., Ortler, K., Binder, N. \& PAll, K. (1999): Indikationslisten für Aufwuchsalgen in Österreichischen Fliessgewassern. Teil 2: Trophieindikation. - 248 pp., Bundesministerium für Land- und Forstwirtschaft, Wien, Austria.

Rimet, F., Ector, L., Cauchie, H.M. \& Hoffmann, L. (2004): Regional distribution of diatom assemblages in the headwater streams of Luxembourg. - Hydrobiologia 520: 105-117.

Round, F.E., Crawford, R.M. \& Mann, D.G. (1990): The Diatoms: Biology and Morphology of the Genera. - 747 pp., Cambridge University Press, Cambridge.

Schaumburg, J., Schranz, C., Foerster, J., Gutowski, A., Hofmann, G., Meilinger, P. \& Schneider, S. (2004): Ecological classification of macrophytes and phytobenthos for rivers in Germany according to the Water Framework Directive. Limnologica 34: 283-301.

Springe, G., Sandin, L., Briede, A. \& Skuja, A. (2006): Biological quality metrics: their variability and appropriate scale for assessing streams. Hydrobiologia 566: 153-172.

Tison, J., Park, Y.-S., Coste, M., Wasson, J.G., Ector, L., Rimet, F. \& Delmas, F. (2005): Typology of diatom communities and the influence of hydroecoregions: a study on the French hydrosystem scale. - Water Research 39: 3177-3188.

UNDERWOOD, A.J. (1991): Beyond BACI: experimental designs for detecting human environmental impacts on temporal variations in natural populations. - Australian Journal of Marine \& Freshwater Research 42: 569-587.

Whitton, B.A., John, D.M., Johnson, L.R., Boulton, P.N.G., Kelly, M.G. \& Haworth, E.Y. (1998): A Coded List of Freshwater Algae of the British Isles. - 274 pp., LOIS publication number 222, Institute of Hydrology, Wallingford.

Zelinka, M. \& Marvan, P. (1961): Zur Prazisierung der biologischen Klassifikation des Reinheit fliessenderGewasser.-Archiv für Hydrobiologie 57: 389-407.

(C) Czech Phycological Society

Received April 25, 2009

Accepted May 21, 2009 